\title{
Galen Medical Journal
}

$\mathrm{W}$ e are delighted to announce the new period of publication of " Galen Medical Journal (GMJ)".

GMJ will focus on novel researches performed by medical students all over the world. No need to say that these studies are inspired supervised and co-written by faculties of medical universities. There has been a growing number of publications and citations from Iranian researchers in recent years.

Our supporting organization, "Student Research Committee of Fasa University of Medical Sciences (SRCFUMS)“, has been one of the most successful counterparts. Members of SRCFUMS have published more than 20 articles in international peer-reviewed journals. (1-4)

It is good but not enough. We aim for novel, goal-directed and problem-solving researches. Manuscripts to be submitted to GMJ, should fulfill a series of intensive criteria including precise methodology, good English and immediate benefits to our readership.

We particularly welcome observational and interventional original studies.

Medical hypotheses section can be a good op- portunity to generate brilliant idea.

It should be kept in mind that scientific misconducts such as plagiarism, duplicate publication and salami publication are officially banned in GMJ. Violators may be introduced to the authorities.

Being involved in "Student- based" research for many years have taught us a lot. Ambition, energy and talent should be translated to disciplined and organized projects. We hope to publish High-qualified and well-written papers.

\section{Editors-in Chief}

Afshin Borhani Haghighi

Associate Professor of Neurology

Shiraz University of Medical Sciences

borhanihaghighi@yahoo.com

borhanihaghighi@gmj.ir

\section{Aliasghar Karimi}

Student Research Committee

Fasa University of Medical Sciences

draliasgharkarimi@yahoo.com

akarimi@gmj.ir

\section{References}

1. Alyasin S, Hamidi M, Karimi AA, Amiri A, Ghaffarpasand F, Ehsaei MJ. Correlation between clinical findings and results of autologous serum skin test in patients with chronic idiopathic urticaria. Southern Medical Journal. 2011;104(2):111.

2. Borhani Haghighi A, Karimi AA, Amiri A, Ghaffarpasand F. Knowledge and attitude towards stroke risk factors, warning symptoms and treatment in an Iranian population. Medical Principles and Practice. 2010;19(6):46872.
3. Kasraeian M, Asadi N, Ghaffarpasand F, Karimi A. Value of transvaginal ultrasonography in endometrial evaluation of non-bleeding postmenopausal women. Climacteric. 2011;14(1):126-31.

4. Khademi S, Ghaffarpasand F, Heiran H, Yavari M, Motazedian S, Dehghankhalili M. Intravenous and Peritonsillar Infiltration of Ketamine for Postoperative Pain after Adenotonsillectomy: A Randomized PlaceboControlled Clinical Trial. Medical Principles and Practice. 2011;20(5):433-7. 